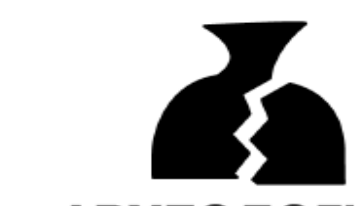

АРХЕОЛОГИЯ

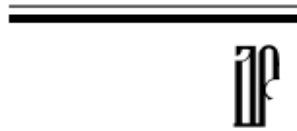

УДК 902.2 ББК 63.4(2) DOI 10.25986/IRI.2019.76.2.009

\author{
Е. В. Столяров \\ ГМЗ «Куликово поле», Тула, Россия stolarov_e@таil.ru \\ А. В. Шеков

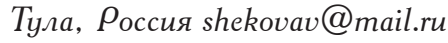 \\ АРХЕОЛОГИЧЕСКИЕ ИССЛЕДОВАНИЯ СРЕДНЕВЕКОВОГО СЕЛИЩА \\ УПА ЗА В ЧЕРТЕ г. ТУЛЫ
}

В статье рассматриваются итоги раскопок поселения XIV - середины XVI в. Упа 3А, расположенного недалеко от исторического џентра г. Тулы. Анализируются находки украшений, культовых и бытовых вешей, комплексов археологической керамики из остатков построек на этом селише. Поселение возникло на рязанско-ордынском пограничье и имело прямое отношение к истории Тулы, которая в середине XIV в. была под властью ордынской администраџии, продолжало существовать некоторое время и после возведения в Туле в первой четверти XVI в. каменной крепости.

Ключевые слова: средневековое поселение, рязанско-ордынское пограничье, археологическая керамика, нумизматические находки

Введение в научный оборот материалов раскопок средневековых поселений, существовавших в черте современной Тулы до возведения здесь к 1520 г. каменной крепости - кремля, важно для историков, располагаюших минимальной информаџией письменных источников о ранней истории этого города [С толяров, Колоколов, Шеков, с. 76]. В 2017 г. нами были опубликованы краткие итоги изучения такого археологического памятника - поселения конџа XIV-XV в. Упа 4 [Столяров, Колоколов, Шеков, с. 76]. Селише Упа $3 \mathrm{~A}$, которому посвяшена настояшая статья, находится на левом берегу р. Упы в 200 м к северо-западу от поселения Упа $4\left(\rho_{\text {ис. }} 1,2\right)$ и в 3 км к юго-востоку от тульского кремля [Столяров, Колоколов, Шеков] $]^{1}$. Памятник был найден в 2013 г. А. М. Воронџовым.

Охранными раскопками 2014 г. было исследовано 1012 кв. м, выявлены два этапа заселения памятника - эпохи раннего железного века (памятники типа Упа 2 конџа I тыс. до н. э. - I в. н. э.), XIV - середины XVI в. [Столяров, л. 9-63]. Культурный слой селища был перекрыт балластом слоем бурого суглинка мощностью до 4 м, который был удален механическим способом. Кроме того, культурный слой в значительной степени был переотложен в итоге многолетней механизированной распашки. Его мошность достигала 0,4 м. К эпохе Средневековья относились остатки семи построек. Они были представлены заглубленными до 1,2 м в материк ямами, имевшими в плане округлые (от 1,5 до

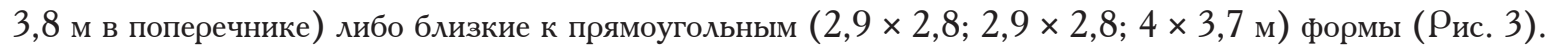

${ }^{1}$ Следует уточнить, что представленная в этой публикаџии на рис. 4:15 находка является нашивной петлей застежки XVII - первой половины XVIII в. [Жилина, 2015, с. 237, рис. 11: 7, 13-17; Сотников, Шпилев, с. 254-256, рис. 6: 5]. 
Явных остатков печей в этих археологических постройках найдено не было, вероятно, они были остатками

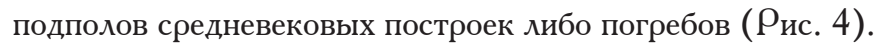

Наиболее ранние средневековые материалы содержала постройка 4. Она имела округлую форму размером до 3,8 м в поперечнике и глубину до 1,2 м. Заполнение было сложено слоями серого и бурого суглинков. Среди находок из заполнения - бронзовый нательный крест с криновидными окончаниями и ромбиком в средокрестии (XIV-XV в.) (Рис. 5: 1) [Седова, с. 54; Археология Романова двора, с. $110-$ 111; Чернов, 2017, с. 319; Шполянская, 2014, с. 261]; два бронзовых витых тройных браслета с петлями на конџах (XII-XIV в.) (Рис. 5: 2, 3) [Седова, с. 94]; пряжка из џветного металла с выступом для язычка (XIII-XIV в.) (Рис. 5: 4) [Андреев, 2018, с. 222]; два бронзовых неорнаментированных пластинчатых браслета (XII-XIV в.) (Рис. 5: 5) [Седова, с. 103-110]; железное калачевидное кресало без язычка (XII-XVI в.) (Рис. 7: 3) [Колчин, с. 99, 101; Штыхов, с. 60; Лысенко, с. 246; Екимов, 2007, с. 80, рис. 17: 7; Хворостова, с. 351]; железный ключ от џилиндрического замка типа В (вторая половина XII -

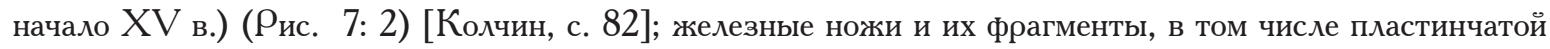
ручки с клепками (XIV-XVI в.) (Рис. 6: 1-3, 5, 6) [Андреев, 2005, с. 66, рис. 4: 1; Археология Романова двора, с. 340, рис. 94: 15]; керамическое пряслиџе; фрагмент железного топора ( Найденные в постройке 352 фрагмента круговой керамической посуды конџа XIII-XIV в. в абсолютном большинстве (92 \%) принадлежали белоглиняным сосудам, изготовленным из формовочных масс без визуально заметных примесей (Рис. 8). Остальные фрагменты керамической посуды имели примеси мелкого песка в формовочных массах. Кроме фрагментов белоглиняной посуды, здесь были найдены Фрагменты посуды, изготовленной из слабоожелезненной глины и фрагменты серо-черного џвета в итоге вторичного обжига. Тридџать шесть фрагментов донџев, в том числе 2 фрагмента с клеймами, имели следы подсыпок песка, а 18 фрагментов донџев, в том числе 2 фрагмента с клеймами, следов подсыпок не имели.

Вероятно, $\mathrm{XV}$ в. следует датировать постройку 3. Она имела в плане овальную форму $(3,2 \times 2,3$ м) и глубину до 1,05 м. Заполнение было сложено слоями темно-серого и бурого суглинков. В верхнем слое были найдены два бронзовых нательных креста с криновидными окончаниями и ромбиками в средокрестиях (XIV-XV в.) (Рис. 9: 1, 2); бронзовый нательный крест позднего варианта крестов с сомкнутыми криновидными окончаниями (XIV-XV в.) (Р рис. 2: 4,5$]$; бронзовый нательный крест с нижним килевидным окончанием и изображением Голгофского креста $(X V-X V I$ в.) ( двора, с. 111]; керамическое пряслиџе и железный черешковый листовидный наконечник стрелы типа 65 (Рис. 9: 5), который фиксировался на памятниках XIII в. и более раннего времени [Медведев, с. 74, табл. 30В, № 61]. Найденные в постройке 340 фрагментов круговой керамической посуды, датируемой, наиболее вероятно, $\mathrm{XV}$ в., изготовлены преимушественно из формовочных масс без визуально заметных примесей (96,5 \%). Двенадџать фрагментов (3,5 \%) имели примеси мелкого песка в формовочных массах. К остаткам белоглиняной посуды принадлежали 298 фрагментов, к посуде, изготовленной из слабоожелезненной глины, - 29 фрагментов, еше 13 фрагментов имели серо-черный џвет. Семнадџать

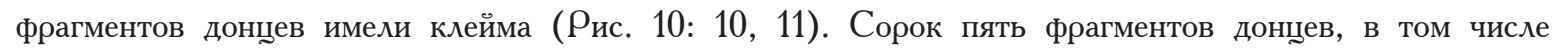
14 фрагментов с клеймами, имели следы подсыпок песка, 13 фрагментов донџев, в том числе 3 фрагмента с клеймами, следов подсыпок не имели.

Наиболее поздняя постройка 7 содержала материалы последней трети XV - первой половины $\mathrm{XVI}$ в. Имела близкую к прямоугольной в плане форму $(4 \times 3,7$ м $)$ и глубину до 1 м. Заполнение было сложено слоями серого и бурого суглинков. Среди находок из постройки - серебряная денга великого

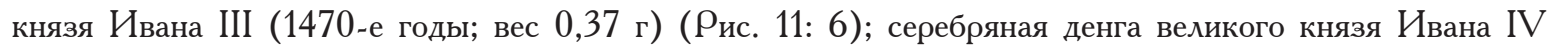
(1535-1547 г.) (Рис. 11: 7)2; фрагмент створки бронзового энколпиона с округлыми окончаниями лопастей, отделенными серповидными выступами, и изображением Распятия с предстояџими (конеџ XV - середина XVI в.) (Рис. 11: 2) [Шполянская, 2008, с. 269-270; Пуџко, с. 72, 73]; бронзовая серьга в виде вопросительного знака (XIV-XVI в.) (Рис. 11: 5) [Седова, с. 16; Жилина, 2018, с. 282 284, рис. 3: 5, 20; рис. 4: 22]; серебряная позолоченная пуговиџа (XVI в.) (

2 Авторы выражают огромную благодарность старшему научному сотруднику ГИМ В. В. Зайџеву за определение нумизматических находок.

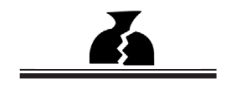


Романова двора, с. 390, рис. 144: 15]. Из 308 фрагментов круговой керамической посуды, найденной в постройке, абсолютное большинство (86 \%) принадлежало белоглиняным сосудам, изготовленным из формовочных масс без визуально заметных примесей $\left(\rho_{\text {ис. }} 12\right)$. Важно, что только один фрагмент венчика из слоя 2 (всего в постройке -25 фрагментов венчиков) и, возможно, некоторые из 8 фрагментов стенок с линейным орнаментом относились к раннему типу белоглиняной «гладкой» посуды (МБК-2, коломенского типа) XVI в. (Рис. 12: 10) [Коваль, с. 251-255]. Остальные фрагменты по морфологии венчиков, орнаментаџии (30 фрагментов стенок с волнистым, волнистым и линейным орнаментами) были аналогичны посуде конџа XIV - XV в., найденной в гончарных горнах на соседнем поселении Упа 4 [Столяров, Колоколов, Шеков, с. 77, 78]. В небольшом количестве такая керамика присутствует в слоях XVI в. на территории Тульского кремля (тип III), где абсолютно доминируют фрагменты белоглиняной «гладкой» посуды (коломенского типа) [Зацаринный, Екимов, Шеков, с. 135, 139, 141, 144, 145, 149 , рис. 1; 16: 3, 5; 18: 1, 9; Коваль, с. 253].

Двадџать семь фрагментов посуды из постройки 7 принадлежали сосудам, изготовленным из слабоожелезненной глины, а 3 фрагмента - красноглиняным сосудам. Кроме фрагментов без заметных примесей в формовочных массах, остальные фрагменты имели примеси мелкого песка. Десять фрагментов донџев, в том числе 1 фрагмент с клеймом, имели следы подсыпок песка, 24 фрагмента донџев, в том числе 3 фрагмента с клеймами, следов подсыпок не имели.

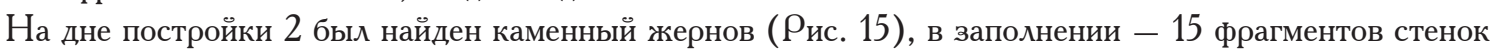
круговых керамических сосудов XIV - XVI в. Остальные постройки были менее интересны. В постройке

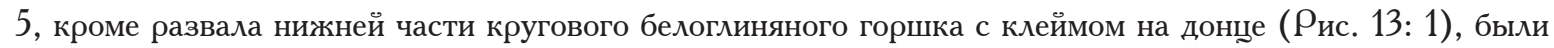
найдены еше 3 фрагмента венчиков от круговых белоглиняных горшков. Два фрагмента венчиков от

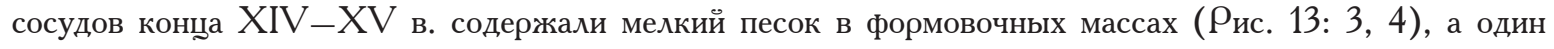
Фрагмент венчика принадлежал белоглиняному «гладкому» горшку XVI в. без заметной примеси в

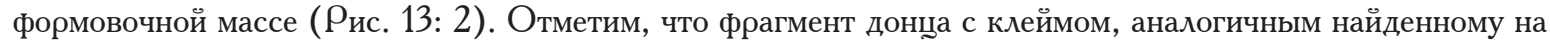
донџе в постройке 5, был обнаружен Ю. Г. Екимовым среди керамики из ямы 3 в ходе раскопок 1992 г. на поселении Упа 4 [Екимов, 1992, л. 124, рис. 70: 10].

В постройке 6 не было обнаружено находок, в том числе фрагментов посуды. В яме 4 был найден керамический комплекс из 62 фрагментов круговой посуды. Среди них - фрагмент с линейным орнаментом по основанию шейки, принадлежавший белоглиняному «гладкому» сосуду без заметных

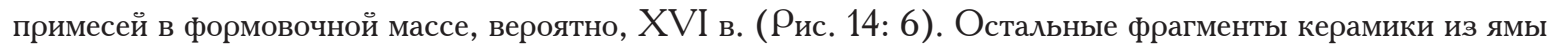

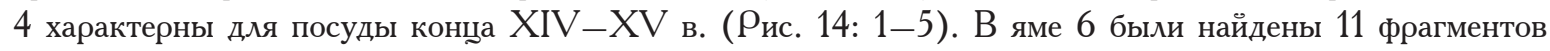
круговой белоглиняной посуды конца $\mathrm{XIV}-\mathrm{XV}$ в. без визуально заметных примесей в формовочных массах (Рис. 16).

Поселение, возникнув, наиболее вероятно, в XIV в., просуществовало до середины XVI в. Однако при публикаџии материалов с соседнего поселения Упа 4 нами были отмечены найденные там веши XI-XIII в. при отсутствии остатков построек с керамическими комплексами этого времени [Столяров, Колоколов, Шеков, с. 76-77]. Добавим, что на соседнем с поселениями Упа 3А, 4 поселении конџа I тыс. до н. э. - первой половины I тыс. н. э. Упа 2, расположенном в 150 м к северо-западу от поселения Упа 3 A, была найдена медная византийская монета - анонимный фоллис императора Романа III Аргира (1028-1034) (Рис. 17: 1). Кроме обнаруженных на поселении Упа 4 и введенных в научный оборот монет XVII - первой четверти XVIII в. [Столяров, Колоколов, Шеков, с. 77, 80, табл. 1], в районе поселений Упа 3А, 4 еше была найдена серебряная польско-литовская монета - полтора гроша короля Сигизмунда III Вазы 1624 г. (место чеканки - Быдгощ; вес - 1,1 г) (Рис. 17: 2).

Таким образом, поселения XIV - середины XVI в. Упа 3A, 4 располагались на территории, которая была освоена в X-XII в. После прекрашения жизни этих поселений и появления Тульской крепости (1507-1509, 1519-1520) эта территория, представлявшая собой ближайшие окрестности города, также была вовлечена в сферу его жизнедеятельности. [Культура средневековой Москвы, с. 9-13; Чернов, 2005, c. 9-12].

Материалы селища Упа-За могут рассматриваться в качестве источника для изучения «ордынского» периода истории Тулы, когда ее «баскаџи ведали» ${ }^{3}$. Представляется, что возможности такого рода источников будут раскрываться по мере изучения их археологических и историко-географических контекстов.

3 ДДГ. №10. С. 29.

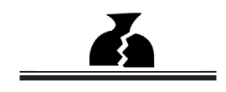


Как уже отмечалось поселения Упа-4, судя по находкам предметов вооружения, имело особый статус. связанный с устройством переправы через Упу или мыта (таможни). Благодаря раскопкам селиџа Упа-3а, расположенного в 200 м от Упа-4, мы можем судить о особенностях материальной культуры рядового населения, жившего в этом районе в XIV-XV в.

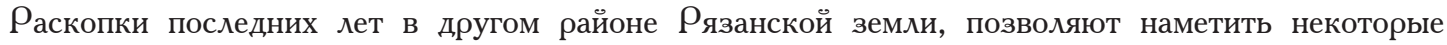
общие черты подобных пограничных поселений. В частности, следует обратить внимание на публикацию С. И. Андреевым материалов раскопок поселения Екатериновка 3 в бассейне $\rho$. Џны (Тамбовская область РСD) [Андреев, 2018]. По мнению автора, поселение возникло около середины XIII в. как пограничный пункт Рязанского княжества на граниџе с Ордой. Возможно, «здесь находились чиновники, ведавшие таможенным сбором» [Андреев, 2018, с. 32]. Поселок перестал существовать в 60-х годах XIV в., хотя окончательно жизнь здесь прекратилась в начале XV в. [Андреев, 2018, с. 220, 230, 232]. Отметим морфологическое сходство значительной части фрагментов круговой керамической посуды с поселений Упа 3А, 4 и Екатериновка 3 [Андреев, 2018, с. 229, тип IV, рис. 21]. Хотя в формовочных массах фрагментов круговой посуды, найденных на поселении Екатериновка 3, присутствовал шамот, другие примеси в большинстве фрагментов отсутствовали [Андреев, 2018, с. 213, 229-230]. Сравниваемые поселения не только находились на рязанско-ордынском пограничье, возможно, здесь размешались таможни, а население пользовалось гончарной посудой, изготовленной в схожих ремесленных традиџиях.

\section{Литература}

Андреев С. И. Юго-Восточная граниџа Рязанского княжества в XII-XIV вв. // Куликово поле и Юго-Восточная Русь в XII-XIV вв. Тула, 2005. С. $62-79$.

Андреев С. И. Поселение Екатериновка 3: к вопросу о юго-восточной граниџе Рязанского княжества // Археология Подмосковья: Материалы научного семинара. М., 2018. Вып. 14. С. 209-235.

Археология Романова двора: предыстория и история џентра Москвы в XII-XIX веках. М., 2009. (Материалы охранных археологических исследований. Т. 12).

Гоняный М. И., Шебанин Г. А., Шеков $А$. В. Предварительные итоги археологического исследования средневекового поселения Котово 1 в Истринском районе Московской области // Археология Подмосковья: Материалы научного семинара. М., 2005. Вып. 2. С. 184-210.

Екимов Ю. Г. Раскопки на поселении Октябрьское 5 и поселении Упа 4 в 1992 г. // Архив ИА РАН. Р-1. № 17159.

Екимов Ю. Г. Археологические исследования территории Тульского кремля в 1999-2000 гг. (раскоп 1) // Позднесредневековый город: археология и история. Сб. статей в 2-х частях. Тула, 2007. Ч. 1. Изучение позднесредневековой Тулы. С. 66-131.

Жилина Н. В. Застежки в костюме Московской Руси (предварительный очерк) // Археология Подмосковья: Материалы научного семинара. М., 2015. Вып. 11. С. 227-253.

Жилина Н. В. Серьги в уборе Московской Руси // Археология Подмосковья: Материалы научного семинара. М., 2018. Вып. 14. С. 278-306.

Зацаринный С. В., Екимов Ю. Г., Шеков А. В. Круговая посуда XVI-XVII вв. из культурного слоя Тульского кремля // Позднесредневековый город: археология и история: Сб. статей. Тула, 2007. Ч. І. С. 132-206.

Коваль В. Ю. Позднесредневековая керамика коломенского типа // Куликово поле и Юго-Восточная Русь в XII-XIV вв. Тула, 2005. С. 251-265.

Колчин Б. А. Железообрабатывающее ремесло Новгорода Великого: (Продукџия, технология) // Труды Новгородской археологической экспедиџии. М., 1959. Т. 2. (Материалы и исследования по археологии СССР). C. 7-90.

Культура средневековой Москвы: Исторические ландшафты. М., 2004. Т. 1.

Лысенко П. ФD. Берестье. Минск, 1985.

Медведев А. Ф. Ручное метательное оружие VIII-XIV вв. М., 1966. (Археология СССР. Свод археологических источников. Е 1-36).

Пуцко В. Г. Христианская металлопластика из окрестностей г. Калуги // Город Средневековья и раннего Нового времени II (V): археология, история. Материалы V Всероссийского семинара. Ноябрь 2013 г. Тула, 2016. C. $72-82$.

Седова М. В. Ювелирные изделия древнего Новгорода (X-XV вв.). М., 1981.

Сотников А. В., Шпилев А. Г. Украшения и металлические детали костюма XVII-XIX вв. из Курской области. Ч. 1 // Город Средневековья и раннего Нового времени: археология, история. Материалы IV Всероссийского семинара. Ноябрь 2011 г. Тула, 2013. С. 242-259.

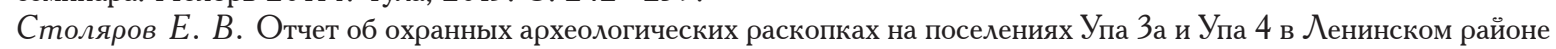
Тульской области в 2014 году. Т. 1 / / Архив Института археологии РАН. 2014. Р-1. Б/н.

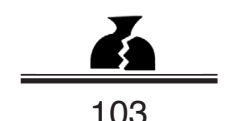


Столяров Е. В., Колоколов А. М., Шеков А. В. Археологические материалы конџа XIV - XV в. с поселения Упа 4 в черте Тулы по раскопкам 2014 г. // Древняя Русь. Вопросы медиевистики. 2017. № 1 (67). С. $76-90$. Хворостова E. А. Спеџиализированные печи XVI в. и конџа XVI - начала XVII в. из раскопок Стариџкого городища / / Тверской археологический сборник. Тверь, 2015. Вып. 10. Т. 2: Материалы V Тверской археологической конференџии... С. 348-359.

Чернов С. З. Домен московских князей в городских станах, 1271-1505 годы. М., 2005. (Культура средневековой Москвы: Исторические ландшафты. Т. 2).

Чернов С. З. Двор с монетными весами в деревне Власьевской близ Звенигорода: «другой» XV век / / Археология Подмосковья: Материалы научного семинара. М., 2017. Вып. 13. С. 309-345.

Шполянская Д. В. Комплекс предметов личного благочестия с селиша XIV-XVI веков Рождествено 1 (предварительное сообшение) // Археология Подмосковья: Материалы научного семинара. М., 2008. Вып. 4. С. 267-275.

Шполянская Д. В. Коллекџия крестов из г. Суздаля / / Славяне и иные языџи... К юбилею Натальи Германовны Недошивиной. М., 2014. (Труды ГИМ. Вып. 198). С. 259-267.

Штыхов Г. В. Древний Полоџк (IX-XIII вв.). Минск, 1975.

\section{References}

Andreev, S. I. Yugo-vostochnaya granica Ryazanskogo knyazhestva v XII-XIV vv. [The South-Eastern Boundary of the Ryazan Principality in the $12^{\text {th }}-14^{\text {th }}$ Centuries]. In Kulikovo pole $i$ Yugo-Vostochnaya Rus' $v$ XII-XIV vv. Tula, 2005. pp. 62-79.

Andreev, S. I. Poselenie Ekaterinovka 3: k voprosu o yugo-vostochnoy granice Ryazanskogo knyazhestva [Settlement Ekaterinovka 3: to the Question of the South-Eastern Border of the Ryazan Principality]. In Arheologiya Podmoskov'ya: Materialy nauchnogo seminara. M., 2018. Vyp. 14. pp. 209-235.

Arheologiya Romanova dvora: predystoriya i istoriya centra Moskvy v XII-XIX vekah [Archeology of Romanov's Court: Background and History of the Center of Moscow in $12^{\text {th }}-19^{\text {th }}$ Centuries]. M., 2009. (In Materialy ohrannyh arheologicheskih issledovaniy. T. 12).

Chernov, S. Z. Domen moskovskih knyazey v gorodskih stanah, 1271-1505 gody [Domain of the Moscow Princes in City Camps, 1271-1505]. M., 2005. (Kul'tura srednevekovoy Moskvy: Istoricheskie landshafty. T. 2).

Chernov, S. Z. Dvor s monetnymi vesami v derevne Vlas'evskoy bliz Zvenigoroda: "drugoy” XV vek [Yard with Coin Scales in the Village Vlasevskaya near Zvenigorod: “Other” XV Century]. In Arheologiya Podmoskov'ya: Materialy nauchnogo seminara. M., 2017. Vyp. 13. pp. 309-345.

Ekimov, Yu. G. Raskopki na poselenii Oktyabr'skoe 5 i poselenii Upa 4 v 1992 g. [Excavations at the Settlement of Oktyabrskoye 5 and the Settlement of UPA 4 in 1992]. In Arhiv IA RAN. R-1. № 17159.

Ekimov, Yu. G. Arheologicheskie issledovaniya territorii Tul'skogo kremlya v 1999-2000 gg. (raskop 1) [Archaeological Researches of Territory of the Tula Kremlin in 1999-2000 (site 1)]. In Pozdnesrednevekovyy gorod: arheologiya $i$ istoriya. Sb. statey v 2-h chastyah. Ch. 1. Izuchenie pozdnesrednevekovoy Tuly. Tula, 2007. pp. 66-131.

Gonyanyy, M. I., Shebanin, G. A., Shekov, A. V. Predvaritel'nye itogi arheologicheskogo issledovaniya srednevekovogo poseleniya Kotovo $1 \mathrm{v}$ Istrinskom rayone Moskovskoy oblasti [Preliminary Results of Archaeological Research of the Medieval Settlement Kotovo 1 in Istra District of Moscow Region]. In Arheologiya Podmoskov'ya: Materialy nauchnogo seminara. M., 2005. Vyp. 2. pp. 184-210.

Hvorostova, E. L. Specializirovannye pechi XVI v. i konca XVI - nachala XVII v. iz raskopok Starickogo gorodishcha [Specialized Ovens of the $16^{\text {th }}$ Century and the End of the $16^{\text {th }}-$ Early $17^{\text {th }}$ Century from the Excavations of the Settlement of Staritsky]. In Tverskoy arheologicheskiy sbornik. Tver, 2015. Vyp. 10. T. 2: Materialy V Tverskoy arheologicheskoy konferencii... pp. 348-359.

Kolchin, B. A. Zhelezoobrabatyvayushchee remeslo Novgoroda Velikogo: (Produkciya, tekhnologiya) [Ironworking Craft of Novgorod the Great: (Production, Technology)]. In Trudy Novgorodskoy arheologicheskoy ehkspedicii. M., 1959. T. 2. (Materialy i issledovaniya po arheologii SSSR). pp. 7-90.

Koval', V. Yu. Pozdnesrednevekovaya keramika kolomenskogo tipa [Late Medieval Ceramics of Kolomna Type]. In Kulikovo pole i Yugo-Vostochnaya Rus' v XII-XIV vv. Tula, 2005. pp. 251-265.

Kul'tura srednevekovoy Moskvy: Istoricheskie landshafty [Culture of Medieval Moscow: Historical Landscapes]. M., 2004. T. 1.

Lysenko, P. F. Berest'e [Berestye]. Minsk, 1985.

Medvedev, A. F. Ruchnoe metatel'noe oruzhie VIII-XIV vv. [Hand Throwing Weapons of the $8^{\text {th }}-14^{\text {th }}$ Centuries]. M., 1966. (Arheologiya SSSR. SAI. E 1-36).

Pucko, V. G. Hristianskaya metalloplastika iz okrestnostey g. Kalugi [Christian Repoussage from Surroundings around the City of Kaluga]. In Gorod Srednevekov'ya i rannego Novogo vremeni II (V): arheologiya, istoriya. Materialy V Vserossiyskogo seminara. Noyabr' 2013 g. Tula, 2016. pp. 72-82.

Sedova, M. V. Yuvelirnye izdeliya drevnego Novgoroda (X-XVvv. $)$ [Jewelry of Ancient Novgorod $\left(10^{\text {th }}-15^{\text {th }}\right.$ Centuries $\left.)\right]$. M., 1981.

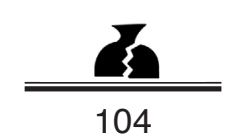


Shpolyanskaya, D. V. Kompleks predmetov lichnogo blagochestiya s selishcha XIV-XVI vekov Rozhdestveno 1 (predvaritel'noe soobshchenie) [A Complex of Objects of Personal Piety from the Settlement of the $14^{\text {th }}-16^{\text {th }}$ Centuries Rozhdestveno 1 (Preliminary Report)]. In Arheologiya Podmoskov'ya: Materialy nauchnogo seminara. M., 2008. Vyp. 4. pp. 267-275.

Shpolyanskaya, D. V. Kollekciya krestov iz g. Suzdalya [Collection of Crosses from the City of Suzdal]. In Slavyane i inye yazyci... Kyubileyu Natal'i Germanovny Nedoshivinoy. M., 2014. (Trudy GIM. Vyp. 198). pp. 259-267.

Shtyhov, G. V. Drevniy Polock (IX-XIII vv.) [Ancient Polotsk $\left(9^{\text {th }}-13^{\text {th }}\right.$ Centuries) ]. Minsk, 1975.

Sotnikov, A. V., Shpilev, A. G. Ukrasheniya i metallicheskie detali kostyuma XVII-XIX vv. iz Kurskoy oblasti. Chast' 1 [Decorations and Metal Details of the Costume of the $17^{\text {th }}-19^{\text {th }}$ Centuries from Kursk Region. Part 1]. In Gorod Srednevekov'ya i rannego Novogo vremeni: arheologiya, istoriya. Materialy IV Vserossiyskogo seminara. Noyabr' 2011 g. Tula, 2013. pp. 242-259.

Stolyarov, E. V. Otchet ob ohrannyh arheologicheskih raskopkah na poseleniyah Upa 3a i Upa 4 v Leninskom rayone Tul'skoy oblasti v 2014 godu. T. 1 [Report about Protective Archaeological Excavations in the Settlements of the UPA 3A and UPA 4 in the Leninsky District of the Tula Region in 2014. Vol. 1]. In Arhiv Instituta arheologii RAN. 2014. R-1. B/n.

Stolyarov, E. V., Kolokolov, A. M., Shekov, A. V. Arheologicheskie materialy konca XIV-XV v. s poseleniya Upa 4 v cherte Tuly po raskopkam $2014 \mathrm{~g}$. [Archaeological Materials of the Late $14^{\text {th }}-15^{\text {th }}$ Century from the Settlement of the UPA 4 within the Tula on the Excavations of 2014]. In Drevnyaya Rus'. Voprosy Medievstiki. 2017. № 1 (67). pp. 76-90.

Zacarinnyy, S. V., Ekimov, Yu. G., Shekov, A. V. Krugovaya posuda XVI-XVII vv. iz kul'turnogo sloya Tul'skogo kremlya [Circular Dishes of the $16^{\text {th }}-17^{\text {th }}$ Centuries from the Cultural Layer of the Tula Kremlin]. In Pozdnesrednevekovyy gorod: arheologiya $i$ istoriya: Sb. statey. Tula, 2007. Ch. I. pp. 132-206.

Zhilina, N. V.Zastezhki v kostyume Moskovskoy Rusi (predvaritel'nyy ocherk) [Clasps in the Costume of Moscow Russia (Preliminary Essay)]. In Arheologiya Podmoskov'ya: Materialy nauchnogo seminara. M., 2015. Vyp. 11. pp. $227-253$.

Zhilina, N. V. Ser'gi v ubore Moskovskoy Rusi [Earrings in the Headdress of Moscow Rus']. In Arheologiya Podmoskov'ya: Materialy nauchnogo seminara. M., 2018. Vyp. 14. pp. 278-306.

\author{
Evgeny V. Stolyarov \\ The State Museum "Rulirovo pole", Tula, Russia \\ Alexandr V. Shekov \\ Tula, Russia
}

\title{
ARCHAEOLOGICAL INVESTIGATIONS AT THE MEDIEVAL SETTLEMENT UPA 3A WITHIN THE TULA CITY
}

The article discusses the results of excavations of the settlement Upa $3 \mathrm{~A}$ of the $14^{\text {th }}-$ the middle of the $16^{\text {th }}$ century, located near the historic center of the Tula City. The findings of the jewelry, cult and household things, the sets of the archaeological ceramics from the remains of the settlement's buildings are examined. The settlement was created over the borderlands of Ryazan and Horde and was directly related to the Tula history, which was ruled by the Horde administration in the middle of the $14^{\text {th }}$ century, it also continued to exist some time after the construction of the Tula stone fortress in the first quarter of the $16^{\text {th }}$ century.

Keywords: medieval settlement, Ryazan and Horde borderlands, archaeological ceramics, numismatic finds 


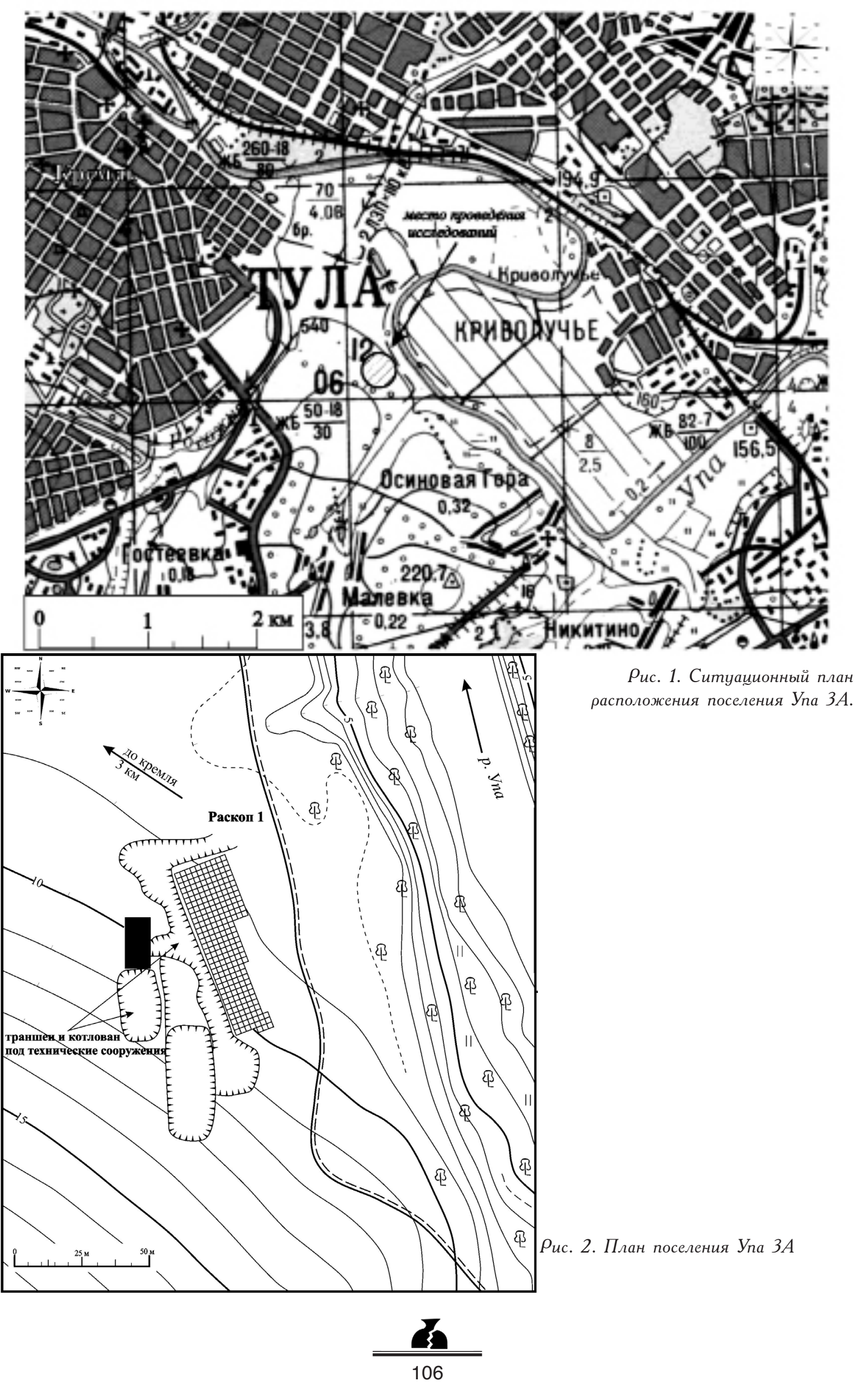



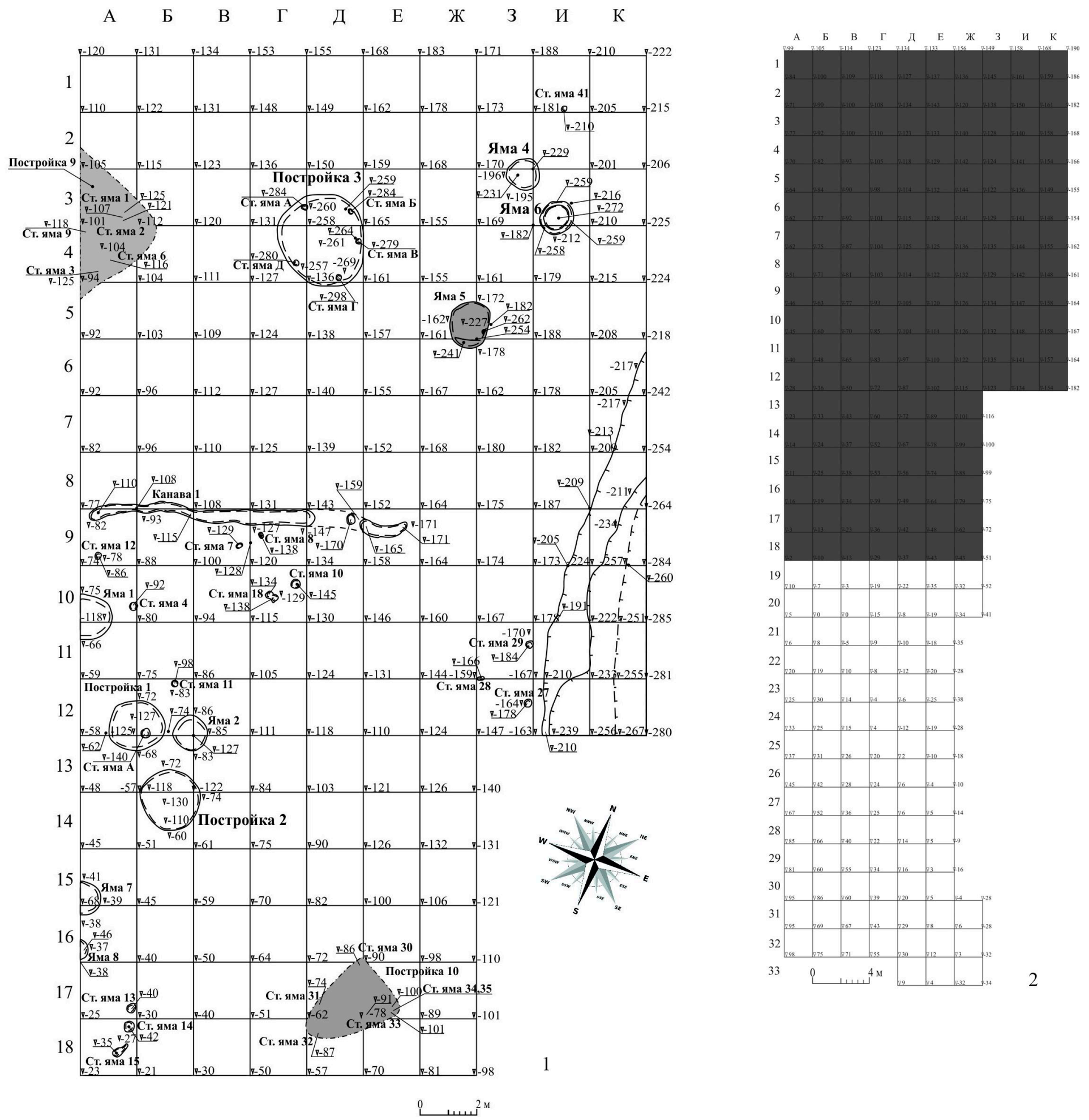

९uc. 3_1. План раскопа 1 на поселении Упа 3 A (1). На схеме (2) выделенный участок показан черным. 

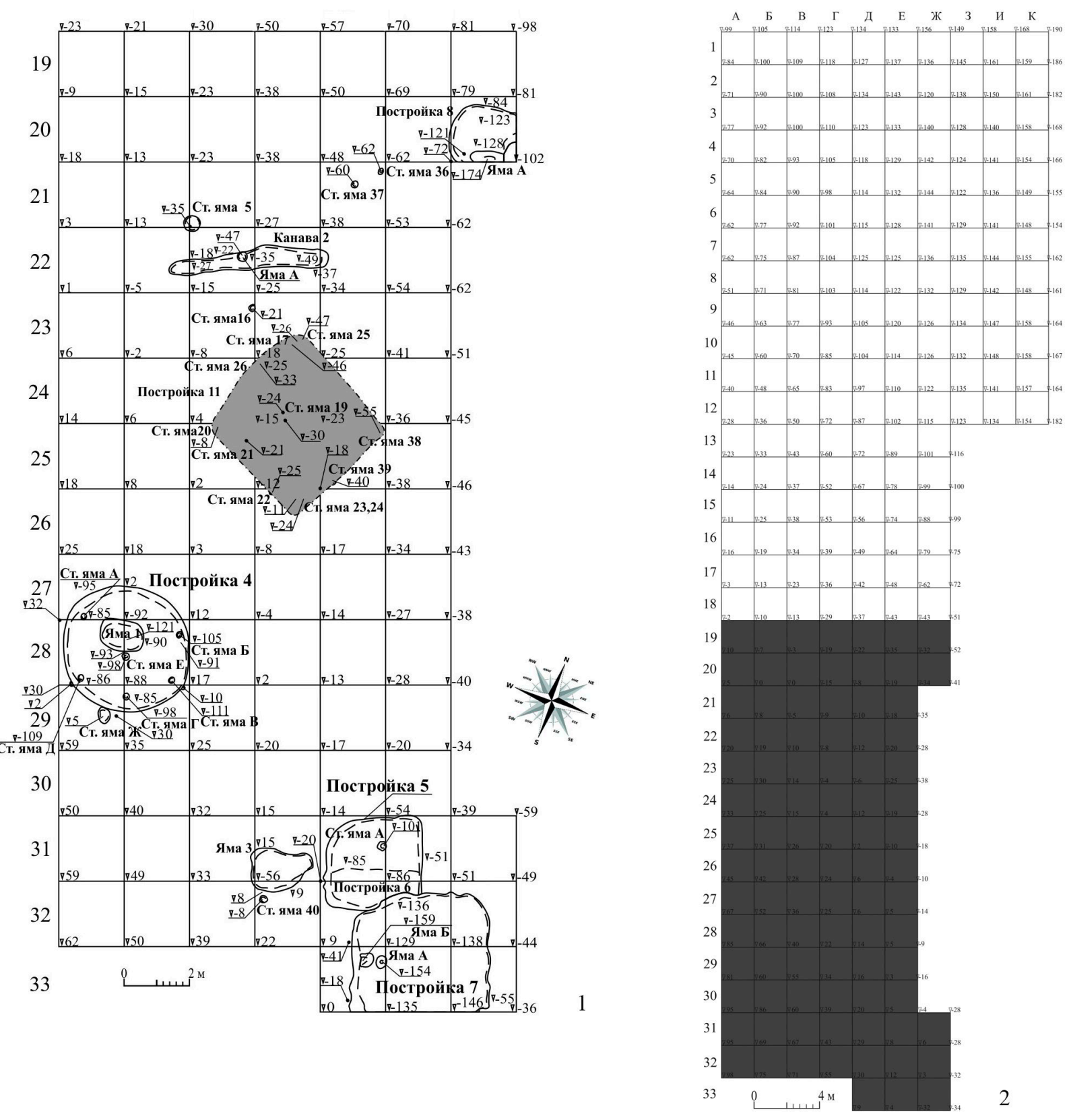

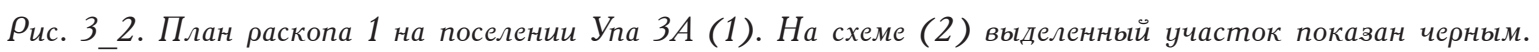



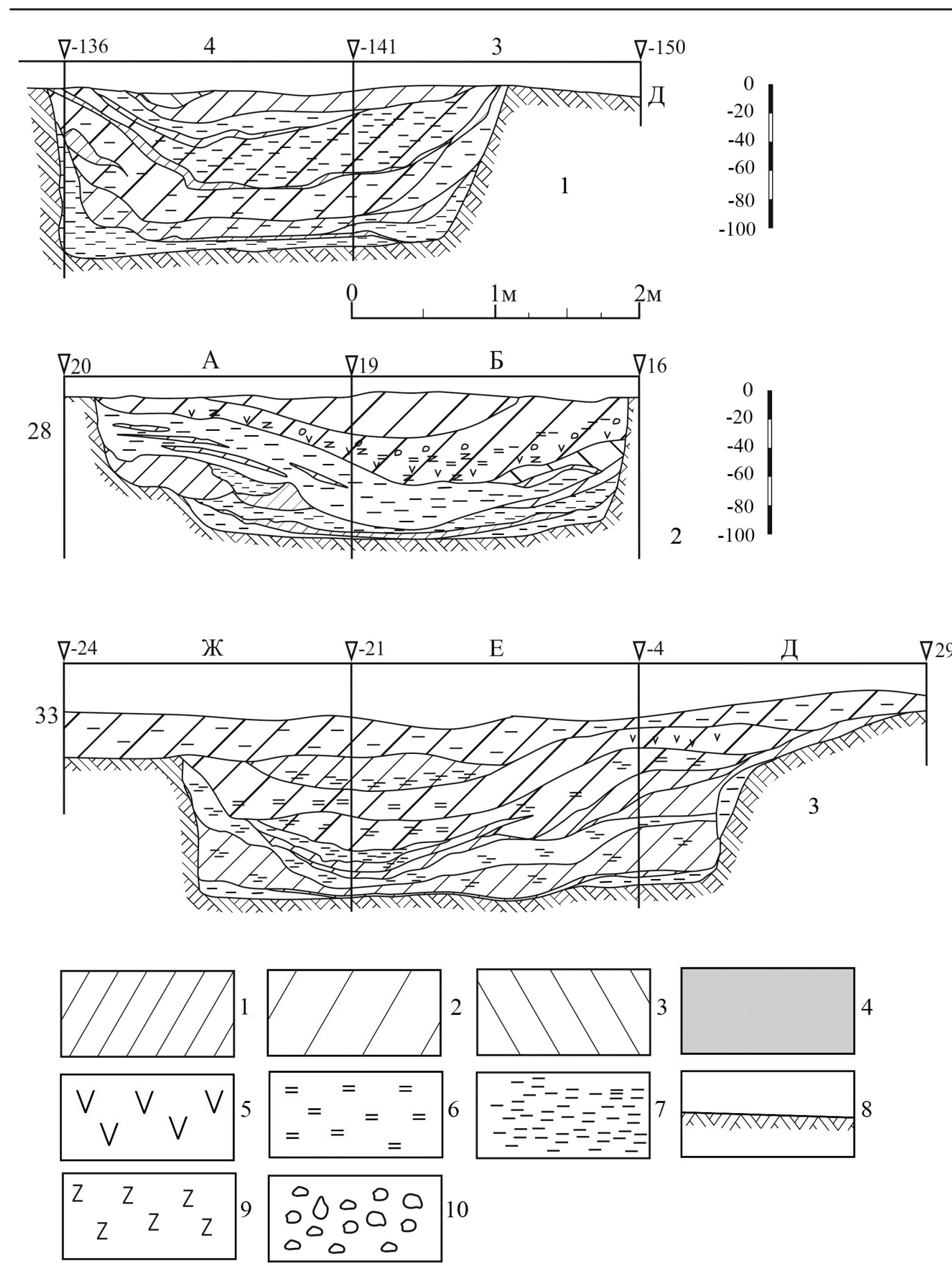

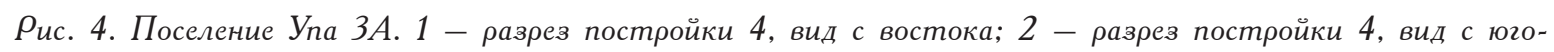
востока; 3 - разрез постоойки 7, вид с севера.

Условные обозначения: 1 - темно-серый суглинок; 2 серый суглинок; 3 - темно-бурый суглинок; 4 объекты раннего железного века; 5 - древесный уголь; 6 - обожженная глина; 7 - ярко-бурый суглинок; 8 - материк; 9 - древесный тлен; 10 - камни.

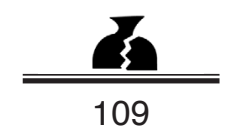



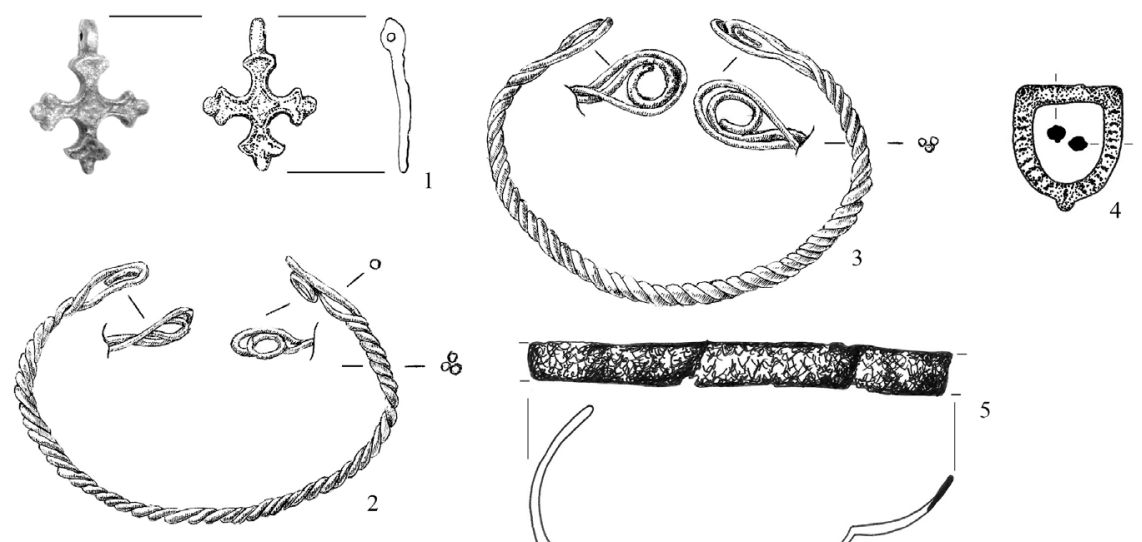

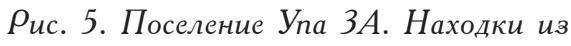
постройки 4: 1 - нательный крест; 2,3, 5,6 - браслеты; 4 - пряжка, 7 - фрагмент изделия. Бронза

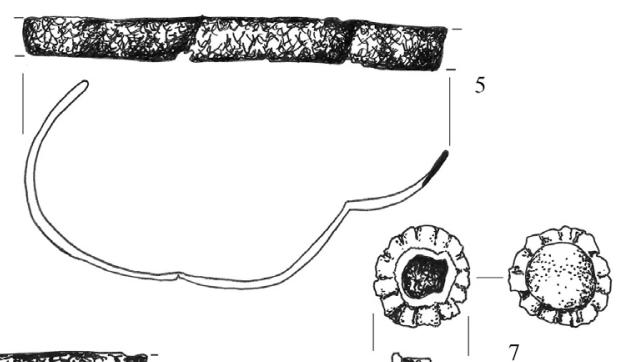

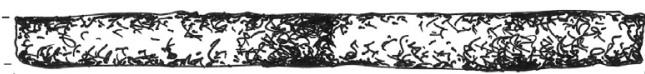

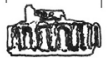
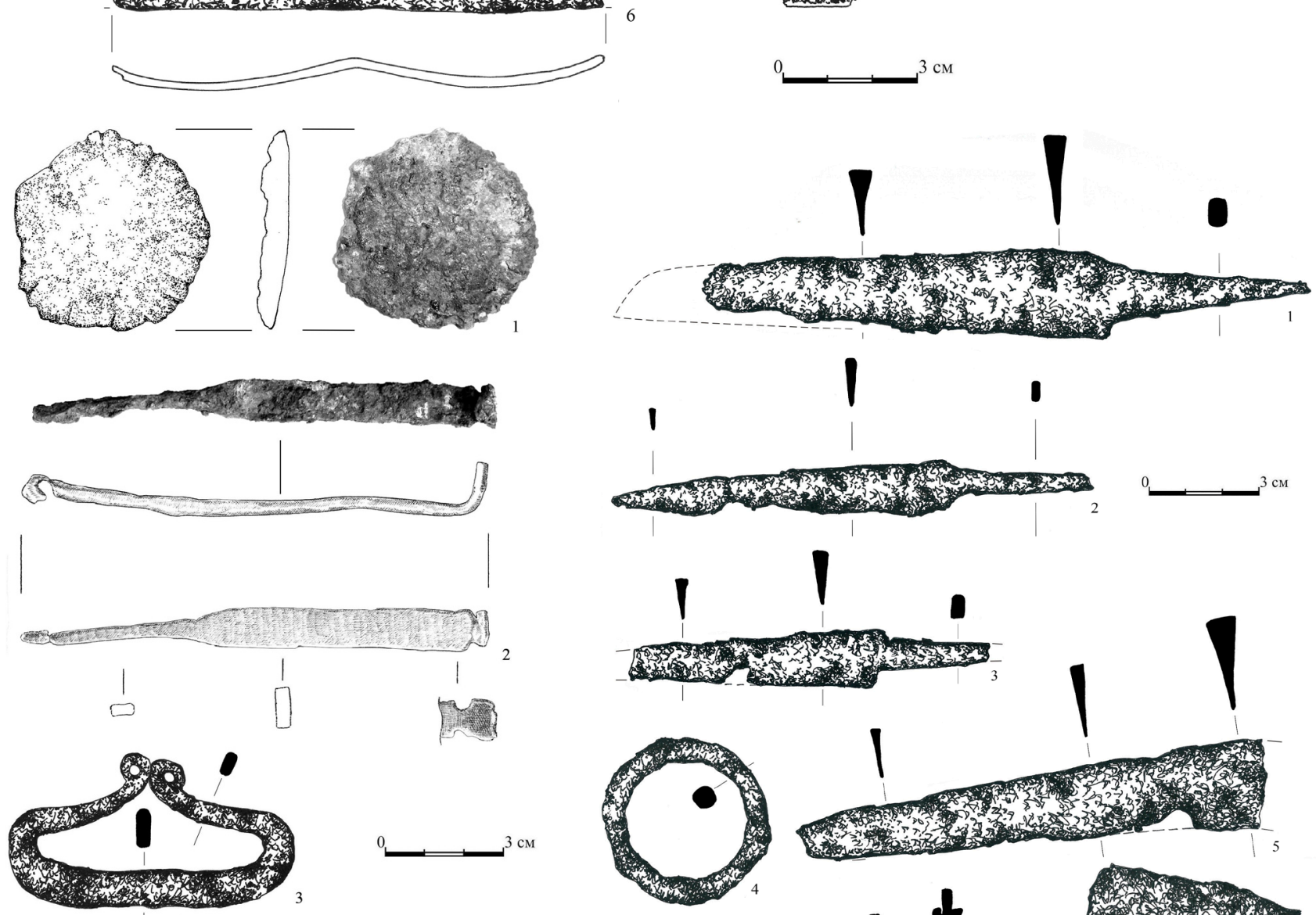

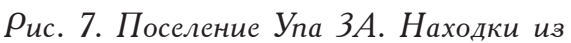
постоойки 4: 1 - изделие; 2 - ключ; 3 - кресало. Железо

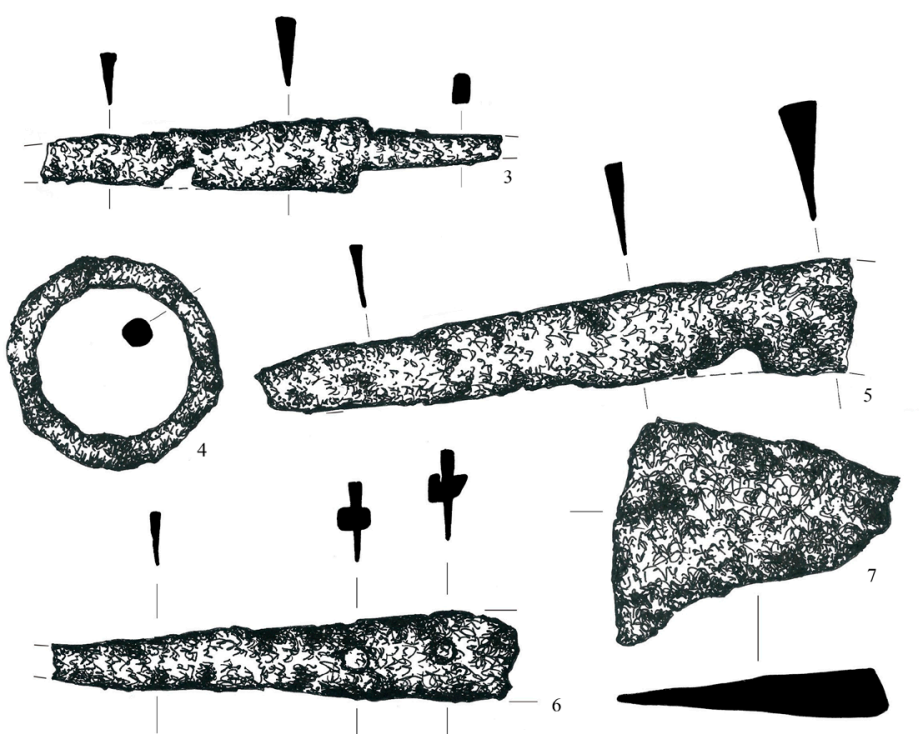

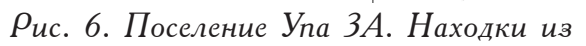
постройки 4: 1-3, 5,6 - ножи и их фрагменты; 4 - сбруйное кольцо; 7 - фрагмент лезвия топора. Железо 

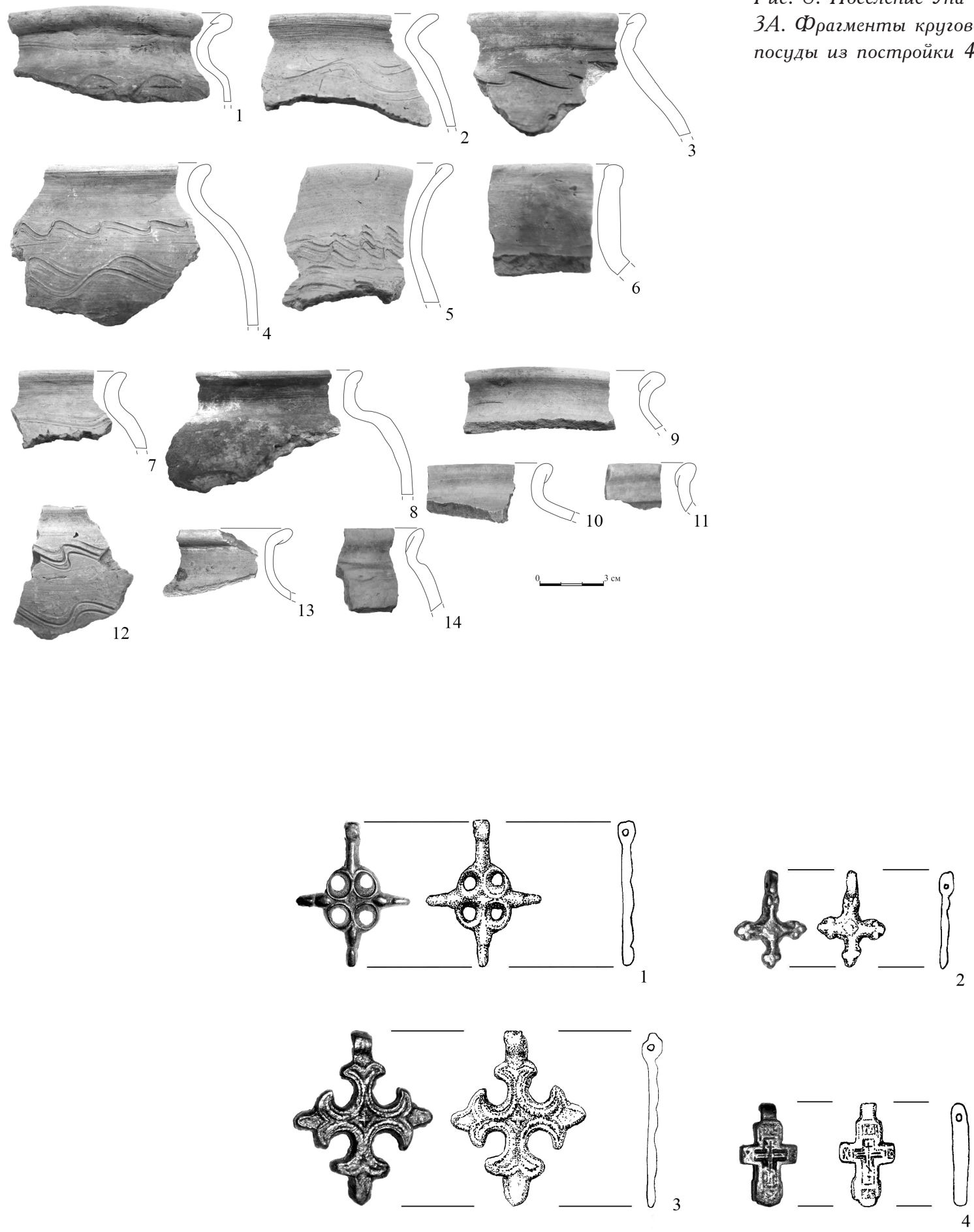

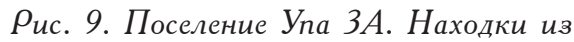
постройки 3: 1-4 - нательные кресты из бронзы; 5 - керамическое пряслице; 6 - железный наконечник стрелы
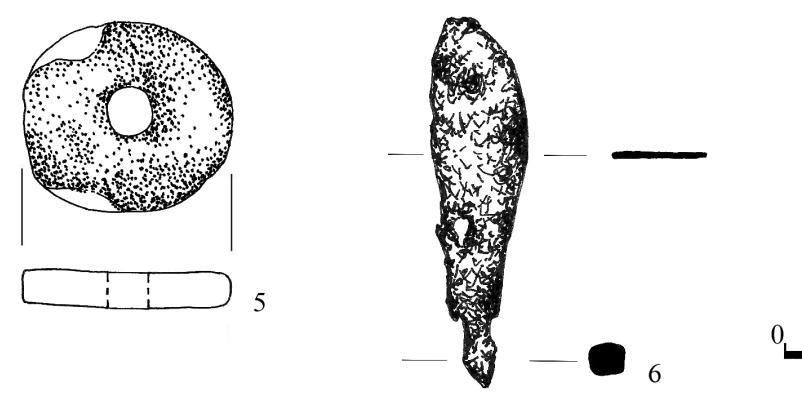


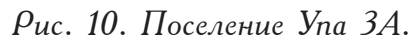
форагменты круговой посуды из постоойки 3
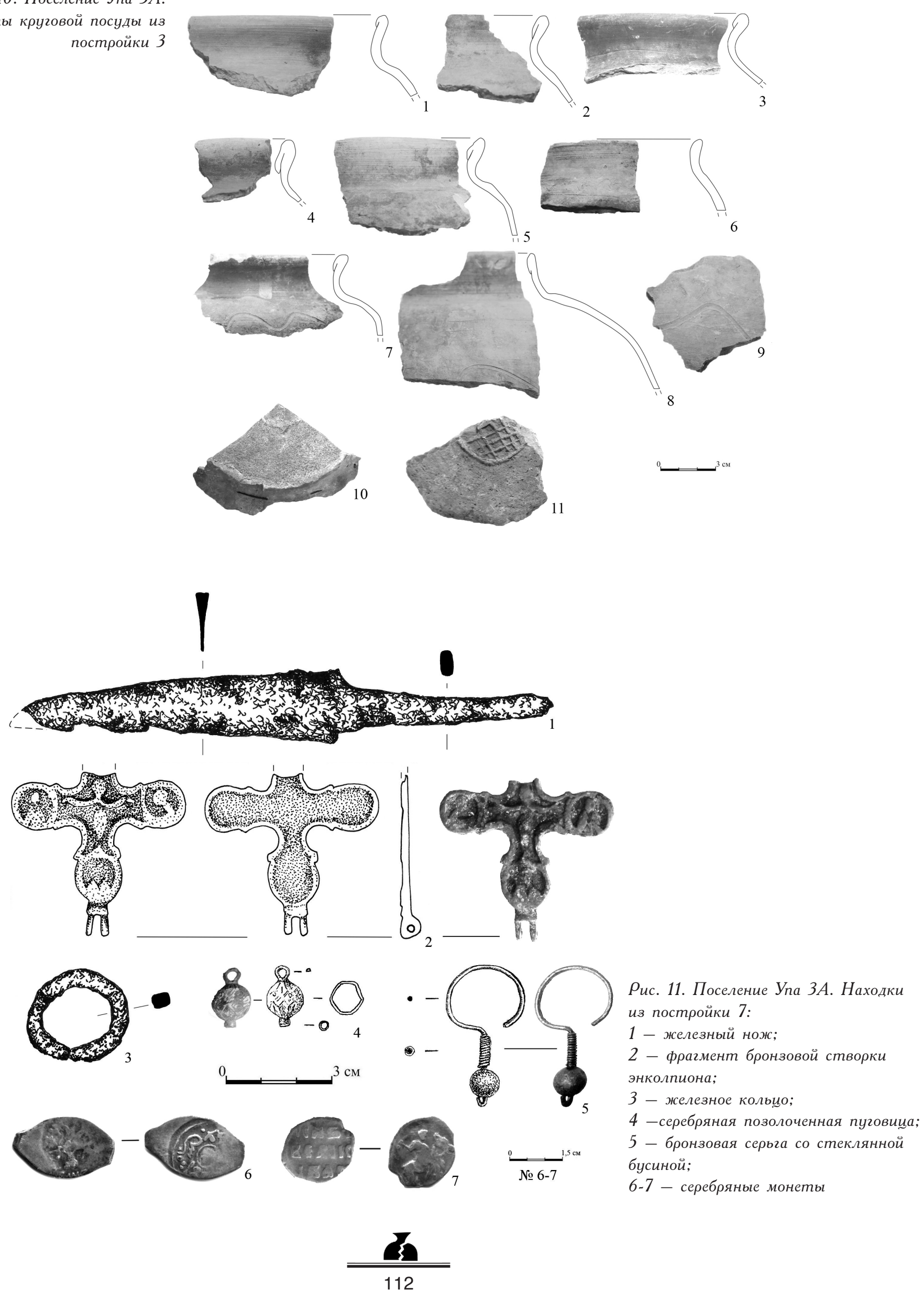


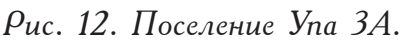

Фрагменты круговой посуды из постройки 7
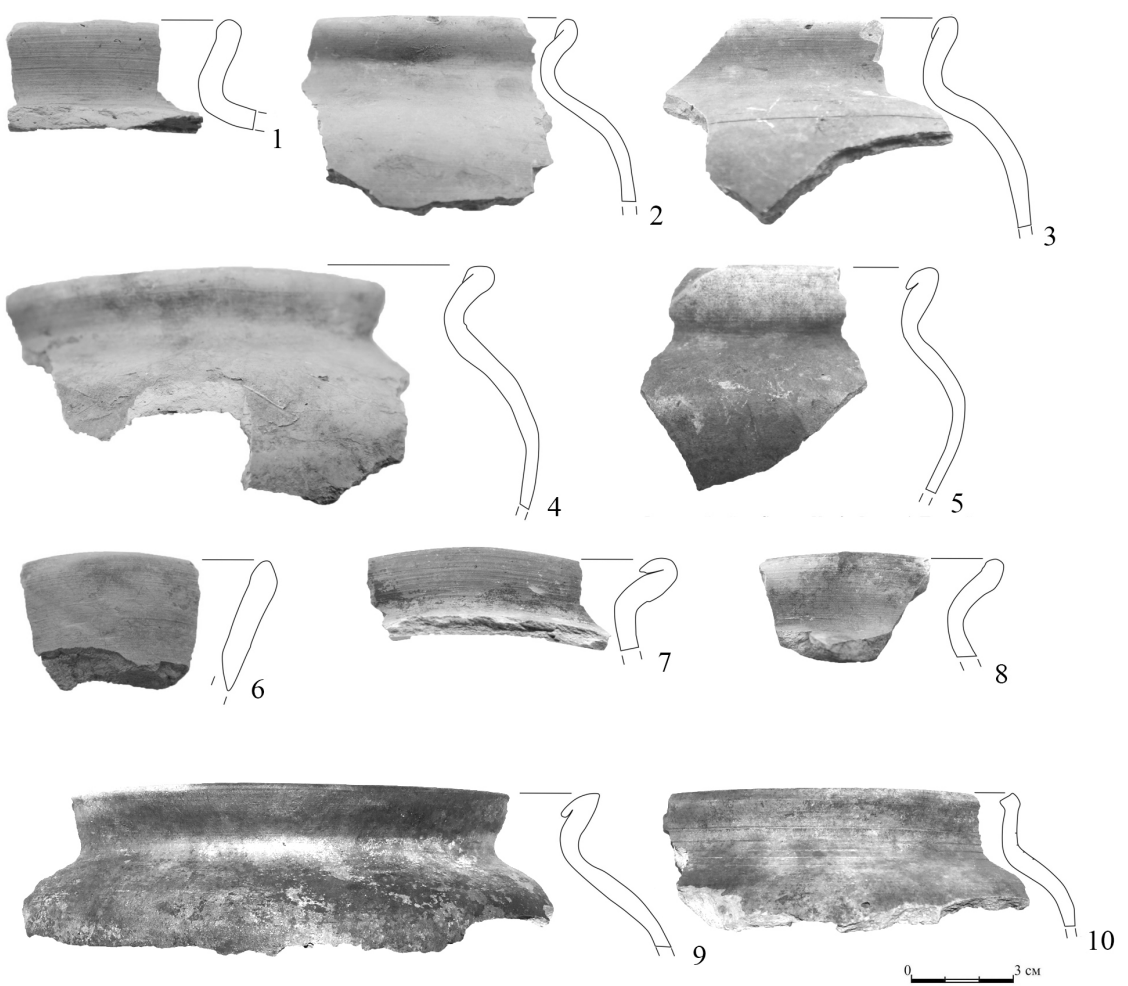

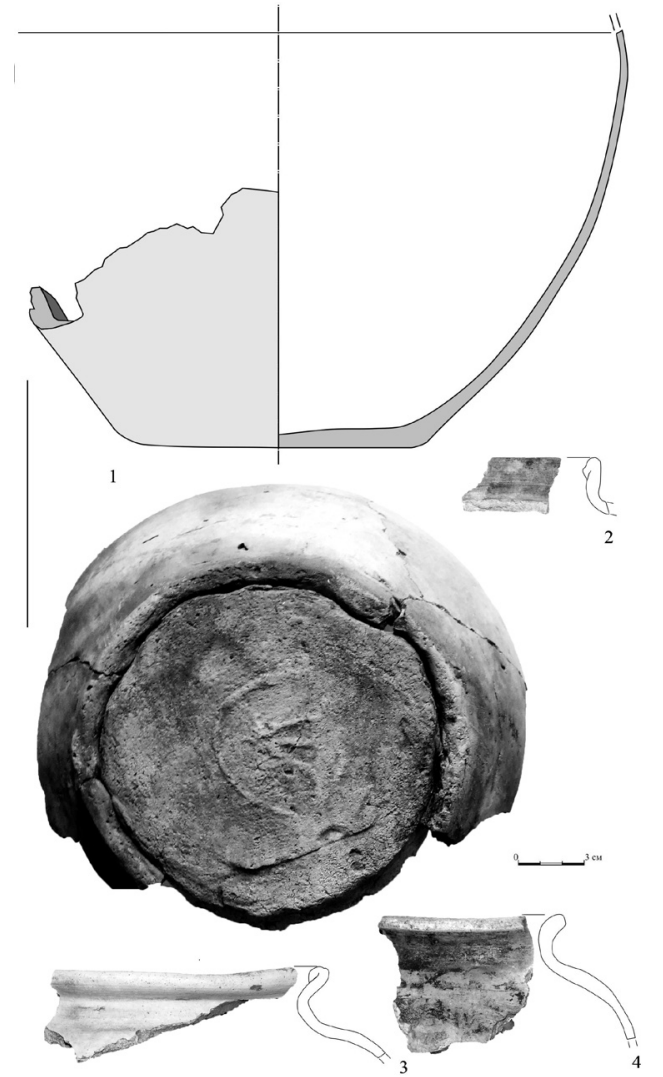

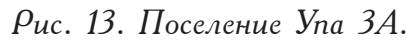

Фрагменты круговой посуды из постоойки 5

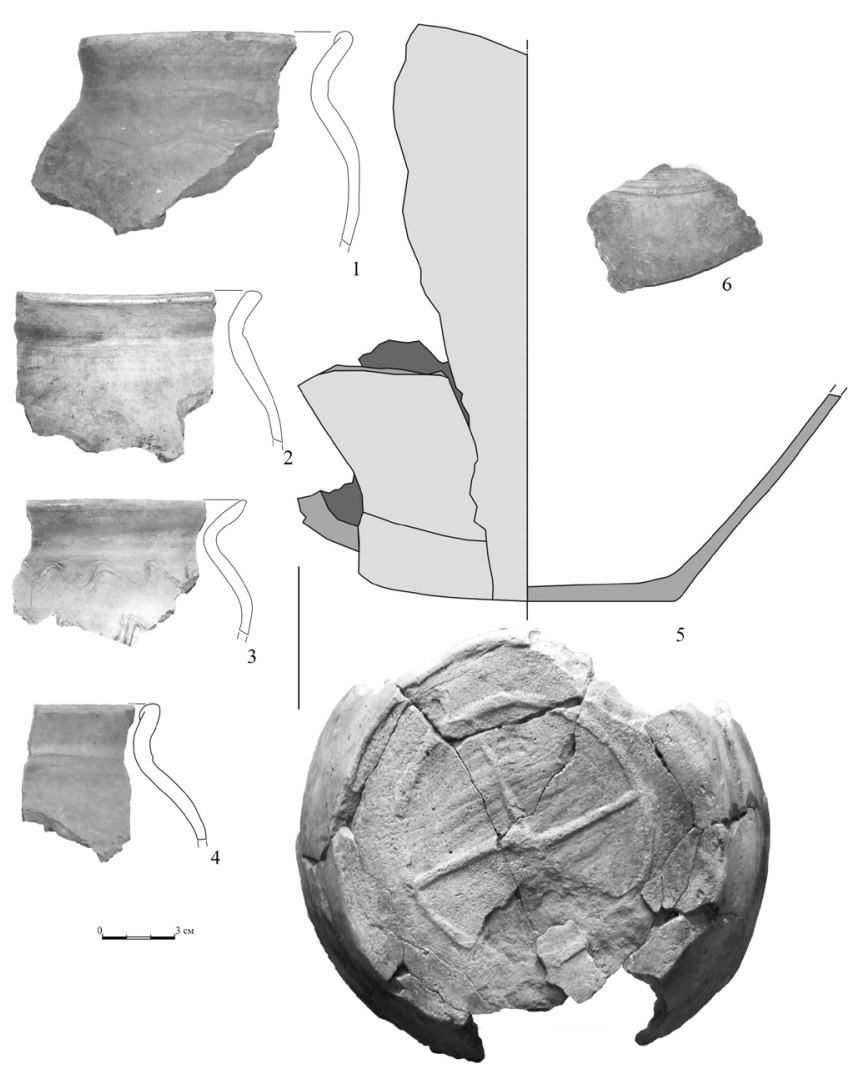

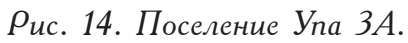
Фрагменты круговой посуды из ямы 4 


\section{Е. В. Столяров, А. В. Шеков}

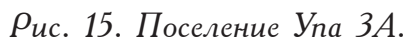
Постоойка 2
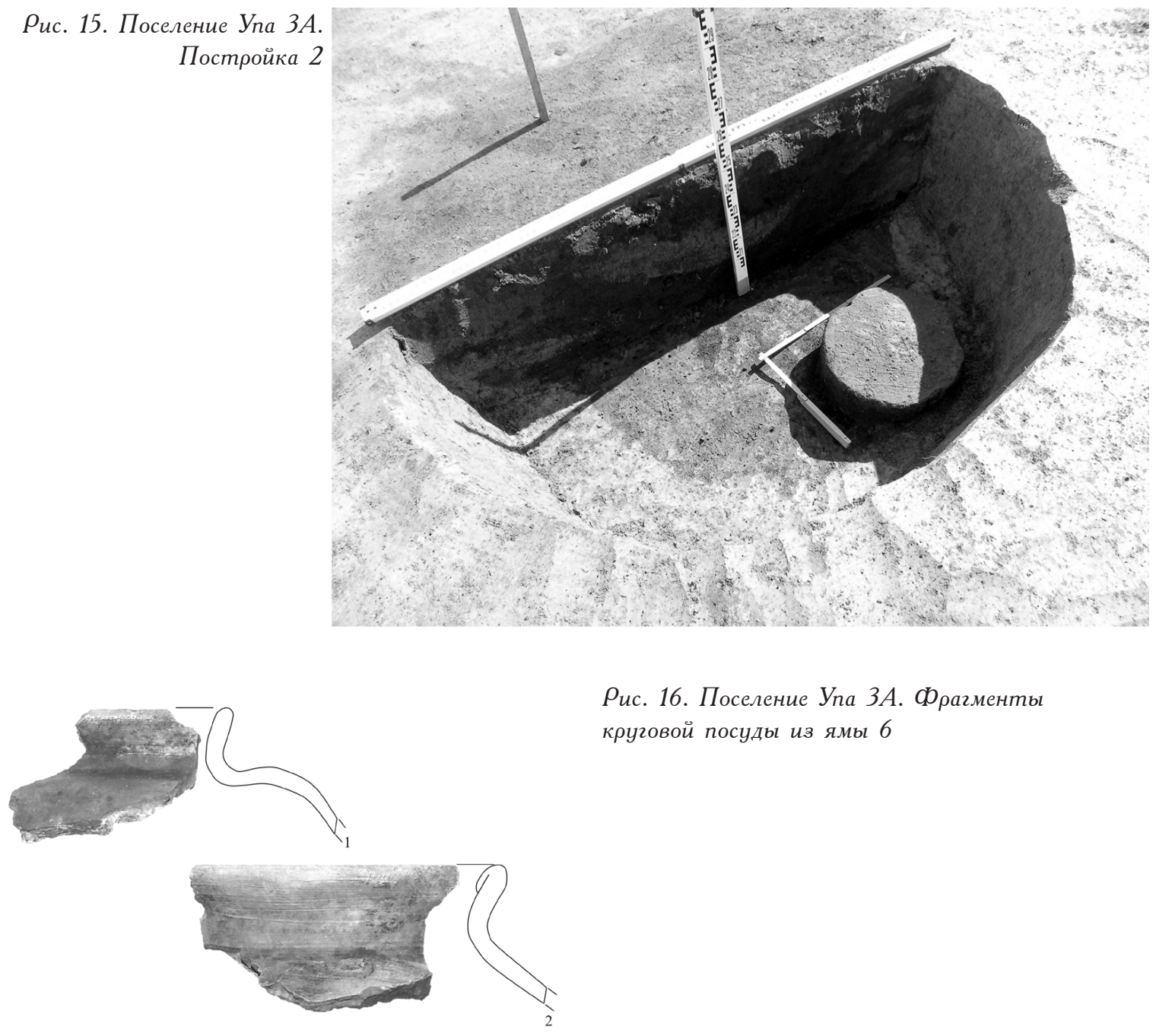

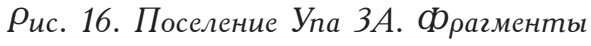
круговой посуды из ямы 6
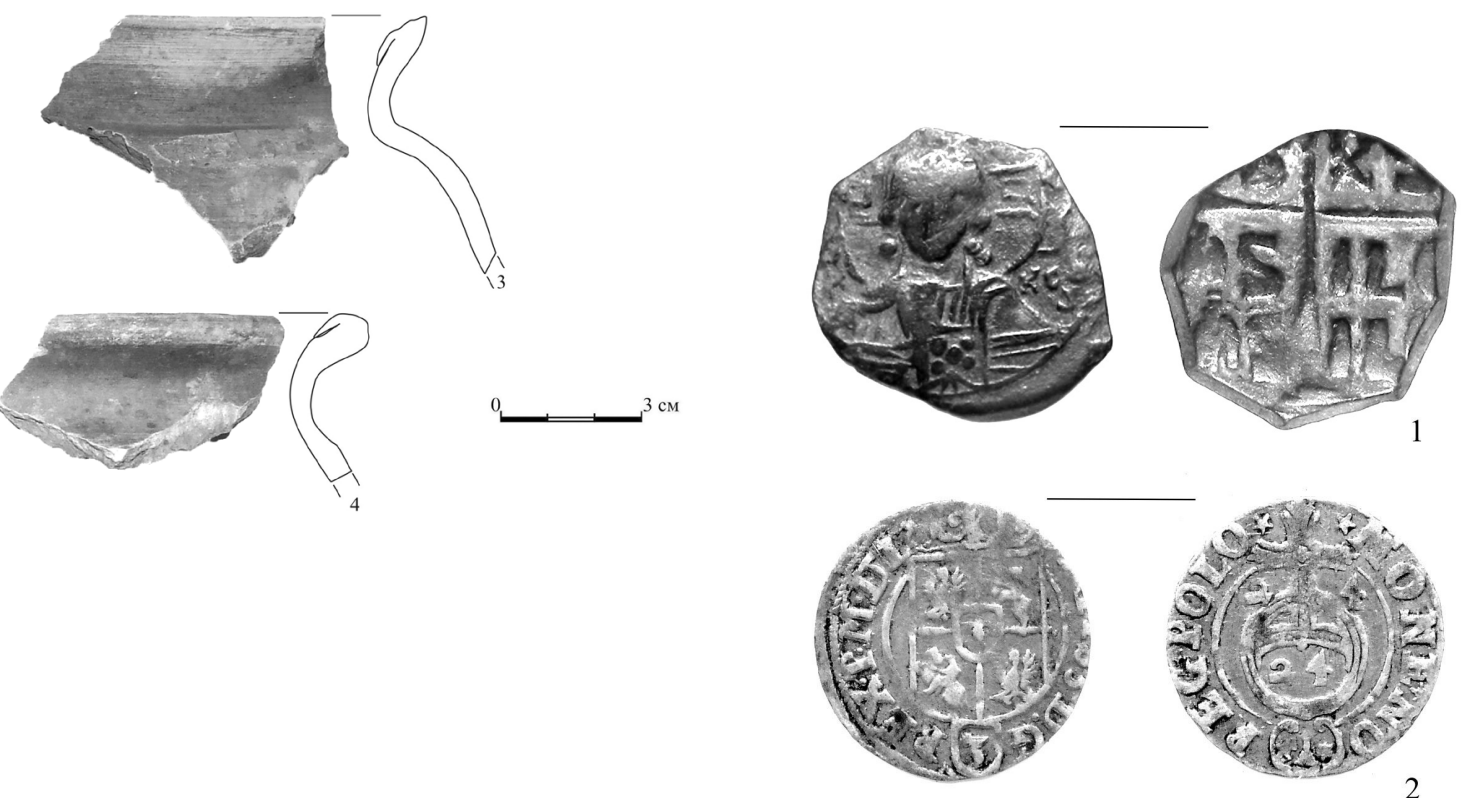

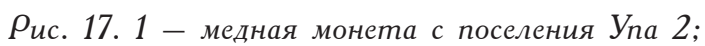

2 - серебряная монета из района поселений Уna $3 A$, Уna 4

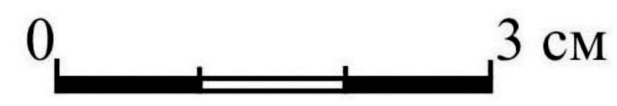

